\title{
Phytochemical Screening and Nutritional Analysis of Some Parts of Celosia argentea $\mathrm{L}$.
}

\author{
MUFIDA FAYAZ $^{1 *}$, MUSADIQ HUSSAIN BHAT ${ }^{1}$, \\ AMIT KUMAR $^{2}$ and ASHOK KUMAR JAIN ${ }^{2}$ \\ ${ }^{1}$ School of Studies in Botany, Jiwaji University, Gwalior-474011, India \\ ${ }^{2}$ Institute of Ethnobiology, Jiwaji University, Gwalior-474011, India \\ mufidafayaz9977@gmail.com
}

Received 1 August 2018 / Accepted 3 September 2018

\begin{abstract}
The present study was aimed to investigate the preliminary phytochemical screening, nutritive value, mineral and heavy metal contents of the leaf, stem and flower of Celosia argentea $\mathrm{L}$. belonging to family Amaranthaceae. Different parts of the plant were subjected to soxhlet using organic solvent such as methanol. A variety of phytoconstituents which include alkaloids, tannins, flavonoids, saponins, carbohydrates, proteins, steroids and amino acids were reported from $C$. argentea which include alkaloids, tannins, flavonoids, saponins, carbohydrates, proteins, steroids and amino acids. All the above phytoconstituents were present in leaf and stem whereas, flower showed the presence of alkaloids, carbohydrates, proteins and steroids. The results obtained indicate that the extracts contain medicinally important bioactive constituents and also heavy metals within the permissible limits. This justifies its use in the traditional medicine for the treatment of various diseases and for edible purposes.
\end{abstract}

Keywords: Celosia argentea, Phytochemicals, Heavy metals, Atomic absorption spectroscopy

\section{Introduction}

Natural products play a vital role throughout the globe in evaluating and prevention of various human diseases. Plants act as an important source of bioactive compounds which are used for the treatment of various human ailments. Medicinal plants possess antifungal, antibacterial and anti-inflammation activities. The most vital of the bioactive constituents of plants include flavonoids, tannins, alkaloids and phenolic compounds ${ }^{1}$. Diets rich in fresh fruits and vegetables are also protective against chronic, degenerative diseases ${ }^{2-4}$.

Medicinal plants play a vital role in traditional medicine and are extensively used as home remedies. During the past decade there has been a significant increase in the utilization of herbal medicine due to their availability, minimal side effects and acceptability to the majority of the population of developing countries. Besides this the past decade has seen an increase in consumption of wild fruits to overcome the malnutrition. 
Celosia species plays a significant role in traditional medicine to cure many diseases like fever, diarrohea, wounds, mouth sores, gonorrhoea, itching, jaundice and inflammation. Celosia argentea L. is a leafy vegetable of the genus Celosia (Amaranthaceae $^{5}$. It is commonly known as plumed cockscomb. Celosia argentea is an herbaceous plant of tropical origin and known for its very brilliant colours and traditional uses ${ }^{6}$. The plant is cultivated in Nigeria by small scale farmers to produce adequate food to satisfy their dietary and economy needs. It is one of the leading vegetables in South Western Nigeria, where it is commonly known as 'soko yòkòtò'. It is used as a vegetable from several other West and Central African countries, tropical and subtropical Asia and America ${ }^{7}$.

C. argentea is an important leafy vegetable crop of high nutritional value ${ }^{8}$. Leaves, tender stems and young flower spikes are cooked into soups, sauces or stews with various ingredients together with other vegetables such as onions and tomato and with meat or fish and palm oil. The soup is consumed with rice, maize, cassava or yam. The young inflorescences are eaten as a potherb.

These days, the attention in phytochemical analysis of medicinal products is growing due to advancement in nutrition, biochemical surveying and mineral prospecting ${ }^{9,10}$. Macro, micro and trace elements play an important role in biological functions in plants and human metabolism. Furthermore, trace elements play a vital role in the formation of bioactive chemical components in medicinal herbs. Thus, they are responsible for many medicinal properties $^{11,12}$.

As a result of the importance of vegetables to our diet which Celosia argentea is inclusive, it is necessary to investigate its nutritional value to increase its consumption rate. The objective of this study was to carry out the preliminary phytochemical screening and quantification of primary metabolites and mineral elements present in Celosia argentea. The phytochemical analysis of the plant is very important commercially and has great interest in pharmaceutical companies for the production of the new drugs for curing of various diseases.

\section{Experimental}

The leaves, stem and flowers of Celosia argentea L. were collected from wild localities of Gwalior, Madhya Pradesh, India. The plant was identified at the Institute of Ethnobiology Herbarium, Jiwaji University Gwalior where a voucher specimen was deposited. The voucher number of the specimen is IOE-447.

\section{Chemicals used}

The chemicals used were procured from SRL Mumbai and HI-MEDIA Pvt. Ltd., Bombay. All the chemicals used were of analytical grade.

\section{Preparation of the extracts}

The different parts of Celosia argentea were washed with tap water, shade dried at room temperature and powdered by a mechanical grinder. From each sample, $5 \mathrm{~g}$ of the plant materials were extracted with $100 \mathrm{~mL}$ of methanol for $8 \mathrm{~h}$ in a Soxhlet apparatus. The crude plant extracts were evaporated to dryness using rotary vacuum evaporator. Extracts were subjected to various qualitative tests for phytochemical screening.

\section{Qualitative phytochemical analysis}

The methanolic plant extracts were analysed for the presence of the phytochemical screening by using the following standard methods: 


\section{Test for alkaloids}

\section{Dragendorff's test}

1 or $2 \mathrm{~mL}$ of Dragendorff's reagent was added to a few $\mathrm{mL}$ of filtrate by the side of the test tube. A prominent yellow precipitate gave positive indication.

\section{Test for tannins}

\section{Alkaline reagent test}

Test solution when treated with sodium hydroxide solution exhibited yellow to red precipitate within short time confirming presence of tannins.

\section{Test for flavonoids}

$2 \mathrm{~mL}$ of extract was treated with 2-3 drops of $20 \%$ sodium hydroxide solution. Formation of deep yellow colour, which becomes colourless on addition of dil. $\mathrm{HCl}$ indicate the presence of flavonoids.

\section{Test for saponins}

\section{Foam test}

To $2 \mathrm{~mL}$ of extract was added $6 \mathrm{~mL}$ of distilled water in a test tube. Then the mixture was shaken vigorously and observed for the formation of persistent foam indicating the presence of saponins.

\section{Test for carbohydrates}

Molish's test

Few drops of Molish's reagent were added to $2 \mathrm{~mL}$ of the extract followed by addition of $2 \mathrm{~mL}$ of conc. $\mathrm{H}_{2} \mathrm{SO}_{4}$ down the side of the test tube. Mixture was then allowed to stand for 2-3 minutes. Formation of a red or dull violet colour at the interphase gave a positive test.

\section{Test for proteins and amino acids}

Millon's test

Extract after treatment with $2 \mathrm{~mL}$ of Millon's reagent showed white precipitate, which turned red upon gentle heating.

\section{Test for steroids}

$2 \mathrm{~mL}$ of acetic anhydride was added to $0.5 \mathrm{~g}$ extract of each sample with $2 \mathrm{~mL}$ of $\mathrm{H}_{2} \mathrm{SO}_{4}$ and was observed for colour change from violet to blue or green.

\section{Determination of nutritive value}

The quantitative estimation of carbohydrates, proteins and fats was carried out using dried material $(100 \mathrm{~g})$. Carbohydrates, proteins, fats were determined quantitatively by standard procedures $^{13}$. The total nitrogen content was determined by Kjeldahl method ${ }^{14}$.

\section{Quantitative estimation of heavy metals and inorganic elements} Sample preparation

Different parts of $C$. argentea were rinsed with tap water and then with distilled water in order to remove surface contamination and dried at 55 to $60{ }^{\circ} \mathrm{C}$ in an electric oven. The dried plant samples were then homogenized in mortar and pestle. 


\section{Digestion and analysis of sample}

$0.25 \mathrm{~g}$ each of the powdered plant samples of $C$. argentea digested in $6.5 \mathrm{~mL}$ of acid solution of $\mathrm{HNO}_{3}, \mathrm{H}_{2} \mathrm{SO}_{4}, \mathrm{HClO}_{4}$ (5:1:0.5). The corresponding solution was heated till white fumes appeared. The solution was then diluted up to $50 \mathrm{~mL}$ by adding distilled water and filtered with Whatman filter paper (No.1). Standard working solutions of elements of interest were prepared to form the calibration curve. Absorption for a sample solution uses the calibration curve to find out the concentration of particular element in the analyzed sample. Perkin Elmer A Analyst 700 model atomic absorption spectrometer (AAS) was used for the determination of eleven metals (K, Mg, $\mathrm{Ca}, \mathrm{Na}, \mathrm{Fe}, \mathrm{Zn} \mathrm{Cu}, \mathrm{Mn}, \mathrm{As}, \mathrm{Pb}$ and $\mathrm{Hg}$ ). Cathode lamps were employed as radiation source. All measurements were carried out in an air-acetylene gas flame. This method is sensitive and selective as other elements in the sample will be unable to absorb the selected wavelength and consequently, doesn't interfere with the measurement. Data were rounded off properly based on the value of standard deviation from measurement conducted in triplicate.

\section{Results and Discussion}

\section{Qualitative phytochemical analysis}

The results of qualitative phytochemical analysis are given in the Table 1. The phytochemical screening in the present study has revealed the presence of alkaloids, carbohydrates, saponins, tannins, proteins, amino acids and steroids. Flavonoids act as primary antioxidants or free radical scavengers. As these compounds were found present in the methanolic extracts of various parts of Celosia argentea, it might be responsible for the potent antioxidant capacity.

Result showed that the nutrients were present in all the parts of Celosia argentea investigated but in varied proportions (Table 2). Starch, total sugar and free sugar were highest in the leaf $(16.2 \pm 1.24 \mathrm{mg} / \mathrm{g}),(63.2 \pm 0.28 \mathrm{mg} / \mathrm{g})$ and $(27.1 \pm 1.13 \mathrm{mg} / \mathrm{g})$ followed by stem and flower. Protein and lipid content were highest in the leaf $(71.4 \pm 0.47 \mathrm{mg} / \mathrm{g})$ and $(13.77 \pm 0.56 \mathrm{mg} / \mathrm{g})$ respectively. Moisture content was highest in stem $81.33 \pm 1.58 \%$ followed by leaf and flower respectively.

Table 1. Qualitative analysis of C. argentea L. in methanol

\begin{tabular}{|c|c|c|c|c|c|c|c|c|}
\hline Phytochemical & Alkaloids & Tannins & Flavonoids & Saponins & Carbohydrates & Proteins & Steroids & Amino acids \\
\hline Leaf & + & + & + & + & + & + & + & + \\
\hline Stem & + & + & + & + & + & + & + & + \\
\hline Flower & + & - & - & - & + & + & + & - \\
\hline
\end{tabular}

Table 2. Nutrient composition of leaf, stem and flower of $C$. argentea $\mathrm{L}$.

\begin{tabular}{ccccccc}
\hline & $\begin{array}{c}\text { Starch, } \\
\mathrm{mg} / \mathrm{g}\end{array}$ & $\begin{array}{c}\text { Total Sugar, } \\
\mathrm{mg} / \mathrm{g}\end{array}$ & $\begin{array}{c}\text { Free Sugar, } \\
\mathrm{mg} / \mathrm{g}\end{array}$ & $\begin{array}{c}\text { Proteins, } \\
\mathrm{mg} / \mathrm{g}\end{array}$ & $\begin{array}{c}\text { Lipids, } \\
\mathrm{mg} / \mathrm{g}\end{array}$ & $\begin{array}{c}\text { Moisture, } \\
\%\end{array}$ \\
\hline Leaf & $16.2 \pm 1.24$ & $63.2 \pm 0.28$ & $27.1 \pm 1.13$ & $71.4 \pm 0.47$ & $13.77 \pm 0.56$ & $81.2 \pm 1.51$ \\
Stem & $12.5 \pm 0.37$ & $57.3 \pm 0.56$ & $24.7 \pm 0.66$ & $29.2 \pm 0.64$ & $4.43 \pm 0.14$ & $81.33 \pm 1.58$ \\
Flower & $2.5 \pm 0.47$ & $36.3 \pm 0.67$ & $11.7 \pm 0.84$ & $21.3 \pm 0.72$ & $4.52 \pm 0.36$ & $71.87 \pm 3.45$ \\
\hline
\end{tabular}

Chemical analysis showed that starch, total sugars, free sugars, proteins and lipids are found to be present in appreciable amounts (Table $2 \&$ Figure 1). The result indicates that these parts are a good source of the nutrients investigated when compared to some other vegetables ${ }^{15}$. The high composition of protein and fat in the leaf indicates that it can be used as food supplements especially for malnourished children and more preferably to other parts. The results are in agreement with the work of Ilodibia ${ }^{16}$, who reported similar results among the several parts of Gomphrena celosioides and Piper guineense who had similar results on the seed of Amaranthus species. 
Table 3. Heavy metal content of leaf, stem and flower of C. argentea $\mathrm{L}$. $(\mu \mathrm{g} / \mathrm{g})$

\begin{tabular}{cccc}
\hline Element & $\mathrm{As}$ & $\mathrm{Pb}$ & $\mathrm{Hg}$ \\
\hline Leaf & $0.08 \pm 0.011$ & $\mathrm{Nil}$ & $\mathrm{Nil}$ \\
Stem & $0.4 \pm 0.03$ & $\mathrm{Nil}$ & $\mathrm{Nil}$ \\
Flower & $0.08 \pm 0.01$ & $0.0018 \pm 0.0001$ & $\mathrm{Nil}$ \\
\hline
\end{tabular}

Table 4. Inorganic elements of leaf, stem and flower of $C$. argentea $\mathrm{L}$.

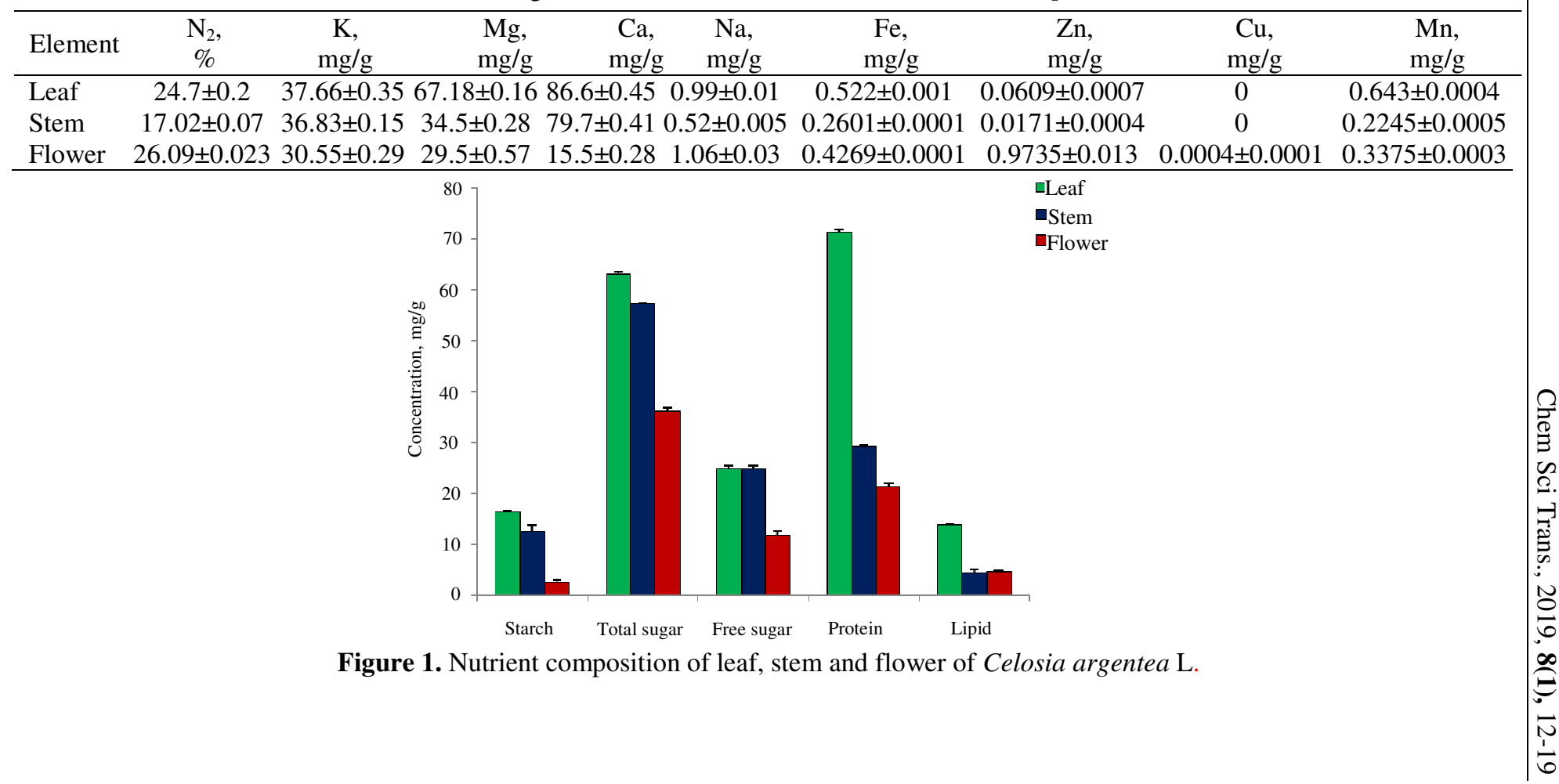




\section{Heavy metals and inorganic elements}

In leaf, stem and flower concentration of Arsenic (As) was $0.08 \pm 0.011(\mu \mathrm{g} / \mathrm{g}), 0.4 \pm 0.03(\mu \mathrm{g} / \mathrm{g})$ and $0.08 \pm 0.01(\mu \mathrm{g} / \mathrm{g})$ respectively and the concentration of $(\mathrm{Hg})$ and $(\mathrm{Pb})$ was nil in leaf and stem and in flower $(\mathrm{Pb})$ was present in $0.0018 \pm 0.0001(\mu \mathrm{g} / \mathrm{g})$ and $(\mathrm{Hg})$ was absent (Table 3 and Figure 3). This concentration was found to be less than the permissible limit set by WHO, so these parts are devoid of heavy metal toxicity. The present study showed that selected parts contain the nutritionally important elements such as $\mathrm{Ca}, \mathrm{Na}, \mathrm{K}, \mathrm{Mg}, \mathrm{Fe}, \mathrm{Zn}$ and Mn (Table 4).

The results also revealed the absence of copper $(\mathrm{Cu})$ in leaf and stem and was present in concentration of $0.0004 \pm 0.0001 \mathrm{mg} / \mathrm{g}$ in flower. Calcium, potassium and magnesium were found to be present in larger amount in leaf followed by stem and flower respectively. Sodium was found to be present in concentration of $0.99 \pm 0.01,0.52 \pm 0.005$ and $1.06 \pm 0.03 \mathrm{mg} / \mathrm{g}$ in leaf, stem and flower respectively. Fe, $\mathrm{Zn}$ and $\mathrm{Mn}$ were found to be in lesser quantities in all selected parts (Figure 2). Nitrogen content was found present in maximum concentration in flower followed by leaf and stem (Figure 4).

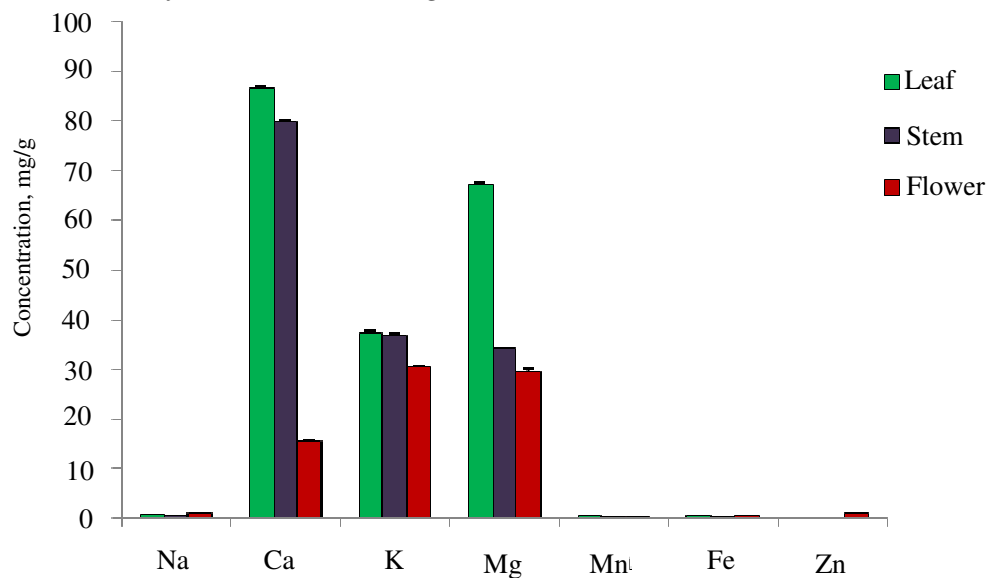

Figure 2. Essential mineral element composition of leaf, stem and flower of C. argentea L.

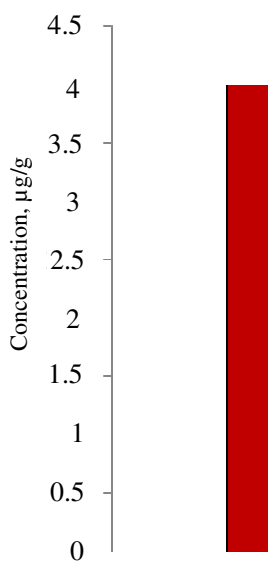

$\mathrm{Cu}$

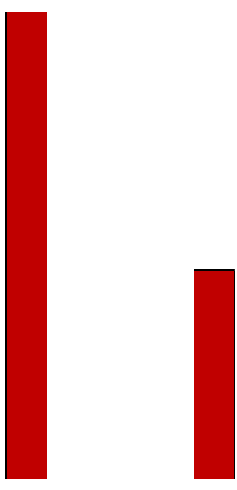

$\mathrm{Pb}$

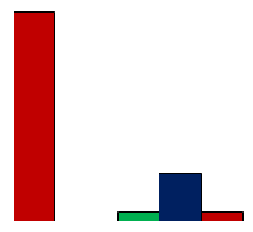

As $\square$ Leaf

- Stem

口Flower

Figure 3. Toxic heavy metal composition of leaf, stem and flower of $C$. argentea $\mathrm{L}$. 


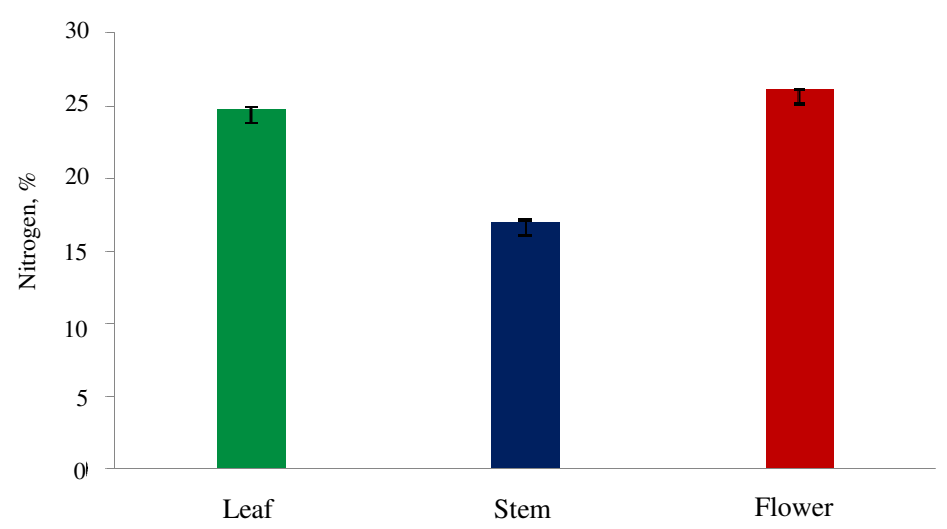

Figure 4. Nitrogen content of leaf, stem and flower of $C$. argentea $\mathrm{L}$.

\section{Conclusion}

The results suggest that the selected parts of $C$. argentea $\mathrm{L}$. have potential medicinal properties due to the presence of high element contents. Furthermore, it showed that the AAS method is a simple, fast and reliable technique to determine the elemental content in plant materials. The study revealed that Celosia argentea is a power house of nutrients. Besides, the leaves which is consumed by people, other parts of the plant should also be used as food. The result of the study revealed that the selected parts have high compositions of crude protein, fat, zinc, iron, calcium, magnesium etc., which designated that Celosia argentea could offer appreciably to human health requirements. The obtained results of the present study justify the usage of these plant parts in daily diet for nutrition and for medicinal purposes.

\section{Acknowledgement}

Authors are highly thankful to Head, School of Studies in Botany for providing needed facilities. The author also thank Jiwaji University, Gwalior for providing financial assistance through research fellowship sanctioned order no. F/DEV./2017/328. Authors are thankful to the Advanced Environmental Testing and Research Laboratory, New Delhi, India, for providing Atomic Absorption Spectroscopy (AAS) facility.

\section{References}

1. Edeoga H O, Okwu D E and Mbaebie B O, J Med Aromatic Plant Sci., 2003, 25, 1010-1015.

2. Joshipura K, Ascherio A, Manson A E , Stampfer M J, Rimm E B, Speizer F E, Hennekens C H, Spiegeleman D and Willett W C, J Am Med Assoc., 1999, 282(13), 1233-1239;DOI:10.1001/jama.282.13.1233

3. Lampe J W, Am J Clin Nutr., 1999, 70, S475-S490; DOI:10.1093/ajcn/70.3.475s

4. Cox B D, Wlichelow M J and Prevost A T, Public Health Nutr., 2000, 3(1), 19-29; DOI:10.1017/S1368980000000045

5. Badra T, Pulses and Vegetables: Underutilized crops. Biochemical Method for Agricultural Sciences. 1993, 85, 29-43.

6. Koh H L, Chua T K and Tan C H, A Guide to Medicinal Plant, an Illustrated, Scientific and Medicinal Approach, World Scientific, Singapore, 2009, 292.

7. Grubben G J H, J Vegetable Plants, 1977, 19(7), 162-169. 
8. Aladesanwa R D, Adenawoola A R and Olowolafe O G, Crop Protection, 2001, 20(4), 321-324; DOI:10.1016/S0261-2194(00)00159-9

9. Niamat R, Khan M A, Khan K Y, Ahmad M, Ali B, Mazari P, Mazhar M and Hussain A, J Appl Pharm Sci., 2012, 2(3), 96-100; DOI:10.7324/JAPS.2012.2316

10. Rodushkin I, Ruth T and Huhtasaari A, Anal Chim Acta, 1999, 378(11-3), 191-200; DOI:10.1016/S0003-2670(98)00635-7

11. Rajurkar N S and Damame M M, Appl Radiat Isot., 1998, 49(7), 773-736.

12. Zhang X, Ding W, Li J, Liu F, Zhou X and Tian S, Rev Bras de Farmacogn, 2015, 25(5), 465-472; DOI:10.1016/j.bjp.2015.07.021

13. AOAC, Methods of Analysis of Association of Official Analytical Chemists $\left(16^{\text {th }}\right.$ Ed.). Washington, D.C., 1997, 1, 600-792.

14. AOAC, AOAC Official Methods of Analysis (16 ${ }^{\text {th }}$ Ed.), Association of Official Analytical Chemists, Washington, D.C., 2005.

15. Ilodibia C V, Chukwu A J, Akachukwu E E, Adimonyemma R N, Igboabuchi N A and Ezeabara C A, Int J Plant Soil Sci., 2016, 11(2), 1-6.

16. Ilodibia C V, Ewere F U, Akachukwu E E, Adimonyemma R N, Igboabuchi N A and Okeke N F, Annual Res Rev Biol., 2016, 10(3), 1-6. 